\title{
Wstęp do rozprawki - oczekiwania a rzeczywistość
}

Wstęp jest uznawany za bardzo istotną część wypowiedzi, kształtującą jej wartość merytoryczną i moc perswazyjną. W artykule przedstawiam, jak sobie radzą $\mathrm{z}$ tworzeniem tej części tekstu uczniowie - w szkolnej wypowiedzi argumentacyjnej zwanej rozprawką. Materiałem badawczym było około stu prac, dotyczących kilku tematów, napisanych przez uczniów klas pierwszych szkół ponadgimnazjalnych różnego typu. Analizie poddano treści wstępów, ich związek z celem wypowiedzi, tematem i główną częścią tekstu. Uzupełnieniem i tłem badań prac uczniowskich jest przegląd czynników mogących kształtować umiejętność tworzenia wstępu do rozprawki.

\section{Do czego służy wstęp wypowiedzi?}

Wstęp to strategiczne miejsce tekstowe, mające ogromny wpływ na komunikatywność, skuteczność i ocenę całej wypowiedzi: „to, w jaki sposób rozpoczniesz (roz)mowę, może mieć - i najczęściej ma - ogromny wpływ na to, jak potoczy się dalsza komunikacja i czy zdołasz dojść do porozumienia ze swoim partnerem"1. Dobry wstęp powinien służyć całości wypowiedzi oraz jej przewidywanemu odbiorcy:

Z punktu widzenia tekstu wstęp (jako „wstęp do”) trzeba rozpatrywać jako integralny składnik całości, który powinien być ściśle — treściowo i formalnie — powiązany z dalszym ciągiem. Dobry wstęp nie może dać się odłączyć od reszty tekstu. [...] Z punktu widzenia czytelnika wstęp (jako

${ }^{1}$ M. Rusinek, A. Załazińska, Retoryka podręczna, czyli jak wnikliwie stuchać i przekonująco mówić, Kraków 2005, s. 96. 
„wstęp dla”) ma za zadanie przyciągnąć uwagę odbiorcy, nawiązać z nim kontakt, przekonać go do dalszej lektury oraz przygotować do tego, co będzie później².

Wstęp to miejsce, w którym nadawca przedstawia się odbiorcy: „dokonuje się inicjalna autoprezentacja, uwiarygodnienie siebie jako tego, kto ma prawo się wypowiadać, zdobywanie przychylności czytelników"3.

Szczegółowe treści, jakie można zawrzeć we wstępie, wiążą się z tematem, sytuacją komunikacyjną, celem wypowiedzi i jej zakładanym odbiorcą. Jolanta Maćkiewicz wyróżnia cztery podstawowe typy początku chętnie wykorzystywane w tekstach:

1. tło tekstu - usytuowanie problematyki w kontekście: przestrzennym, czasowym, problemowym itp.; należy zadbać o to, by tło było dopasowane do tematu i nie za obszerne;

2. prezentacja tekstu - na przykład informacje o autorze, problematyce, motywacja napisania, plan tekstu;

3. argumentacyjny - teza lub hipoteza, pytanie retoryczne, seria pytań;

4. przyciągający - ciekawa historia, anegdota; opowiadanie o jednostkowym, konkretnym zdarzeniu; charakterystyczny lub intrygujący przykład; dane liczbowe; trafny, zaskakujący lub przewrotny cytat, wypowiedź eksperta lub autorytetu; metafora, porównanie analogia, paradoks ${ }^{4}$.

Wymienione sposoby mogą oczywiście współwystępować we wstępie, a ich waga i stosowność zależą od konkretnych okoliczności.

Podstawowymi wadami wstępu, bez względu na typ tekstu, są rozwlekłość i banalność (ogólniki, truizmy). Maćkiewicz przestrzega: „Niezależnie od tego, w jaki sposób rozpoczynamy tekst, powinniśmy unikać jednego — pokusy wielosłowia”, a Piotr Wierzbicki dodaje: „Pisanie rzeczy ogólnie znanych jest marnotrawstwem czasu i wysiłku. Najpierw traci czas ten, kto pisze, potem traci niepotrzebnie czas ten, kto to musi czytać"6. Autor Ćwiczeń stylistycznych uznaje ogólnikowe wstępy i zakończenia nie na temat za niezmiernie szkodliwą plagę różnego rodzaju tekstów. W odniesieniu do sytuacji szkolnej wprost twierdzi, że „Tysiąc razy lepsze jest wypracowanie w ogóle bez wstępu i zakończenia niż wypracowanie z ogólnikowym wstępem i ogólnikowym zakończeniem nie na temat"7. Trzeba jednak mieć świadomość, że komunałów nie da się całkiem uniknąc ${ }^{8}$, a oszczędnie stosowane mogą pełnić ważne funkcje w komunikacji (por. uwagi o przemawianiu).

\footnotetext{
2 J. Maćkiewicz, Jak dobrze pisać. Od myśli do tekstu, Warszawa 2010, s. 29-30.

${ }^{3}$ Ibidem, s. 15.

${ }^{4}$ Ibidem, s. 33-35.

5 Ibidem, s. 35.

${ }^{6}$ P. Wierzbicki, Ćwiczenia stylistyczne, Warszawa 1977, s. 106.

7 Ibidem.

${ }^{8}$ M. Rusinek, A. Załazińska, op. cit., s. 76.
} 
Wagę początku wypowiedzi dostrzega się i podkreśla w stosunku do konkretnych sfer komunikacji i gatunków. Do najstarszych należą zalecenia retoryczne:

Wstępy do mów należy opracowywać z całą starannością i jasnością, winny one być bogate w myśli, trafne w wyrazie, a zwłaszcza dobrze dostosowane do przedmiotu, o którym się traktuje. Bo pozytywny osąd i siła przekonania mówcy zależy w dużej mierze od wstępu, a ten winien słuchacza od razu zająć i pociągnąć ${ }^{\text {. }}$.

Podczas przemawiania szczególnie istotne są dwa wymiary początku. Pierwszy wymiar jest związany z osobą odbiorcy, który ma zostać, jak zaleca Cycero, „zajęty” i „pociągnięty” — czyli otrzymać wstęp atrakcyjny. Ponieważ kategoria atrakcyjności jest pojęciem względnym i subiektywnym, nie da się wskazać prostej i pewnej drogi do jej osiągnięcia. Anna Starzec przyjmuje, że atrakcyjność tekstu wiąże się między innymi ze: stanem wiedzy o świecie odbiorcy, oczekiwaniami odbiorcy, emocjonalnym stosunkiem do tematu, sprawnością komunikacyjną, stopniem zaangażowania ${ }^{10}$. Niezależnie od profilu odbiorcy atrakcyjne i przyciągające uwagę człowieka zwykle bywa to, co nowe (na przykład preferencja nowości występująca już u niemowląt ${ }^{11}$ ), nieoczekiwane, inne niż zwykle; przykuwają uwagę rzeczy ekstremalne, o dużym natężeniu (dlatego interesują nas rekordy), sprzeczne z oczekiwaniami i przyzwyczajeniami. Stąd też działania językowe, które poza możliwością pełnienia innych funkcji są związane z uatrakcyjnianiem tekstu, to: dynamizowanie, przyciąganie uwagi, zaskakiwanie, rozbawianie, skłanianie do aktywności, interakcji ${ }^{12}$.

Drugi ważny wymiar wstępu do wystąpienia retorycznego dotyczy relacji między nadawcą a odbiorcą. Na początku interakcji nadawca stara się przekazać pewną wiedzę (w odpowiedniej ilości), która ma między innymi posłużyć temu, by między nim a słuchaczami wytworzyła się więź, choćby pozorna i krótkotrwała. „Płaszczyznę porozumienia wyznaczają w retoryce miejsca wspólne zwane toposami, czyli takie zdania, kwestie, obiegowe sądy, schematy i obrazy, które są jednakowo rozumiane i przyjmowane przez mówcę i słuchaczy"13. Nie mają one wartości informacyjnej, stąd też można by uznać je za zbędne lub szkodliwe, jednak ich wartość w tej sytuacji polega na budowaniu poczucia wspólnoty. Dlatego Michał Rusinek i Aneta Załazińska zauważają, że „Komunały mogą być bardzo przydatne, ale jeśli mówcy posługują się nimi oszczędnie i jeśli stanowią one jedynie szkielet, pozwalający wyznaczyć płaszczyznę dla właściwej komunikacji”" ${ }^{4}$.

Początek tekstu jest niezmiernie istotny również w sferze medialnej, ma bowiem zachęcić odbiorcę do zapoznania się z resztą przekazu. Wielokrotnie przypominają o tym autorzy Biblii dziennikarstwa - Renata Gluza pisze, że dobry

\footnotetext{
${ }^{9}$ Cycero, $O$ mówcy, cyt. za: J. Maćkiewicz, op. cit., s. 29.

10 A. Starzec, Wspótczesna polszczyzna popularnonaukowa, Opole 1999, s. 172.

11 M. Jagodzińska, Psychologia pamięci. Badania, teorie, zastosowania, Gliwice 2008, s. 146.

12 A. Starzec, op. cit., s. 172.

${ }^{13}$ M. Rusinek, A. Załazińska, op. cit., s. 73.

14 Ibidem, s. 76.
} 
początek artykułu to „pięćdziesiąt procent sukcesu, przy czym jego zadaniem jest nie tylko zaciekawienie czytelnika, ale też zaprezentowanie tematu artykułu"15. Wskazuje na rolę konkretu, obrazu: „Nie zaczynaj od tak zwanego ogólnego wstępu — to najczęstszy błąd popełniany przez dziennikarzy [...]. Pamiętaj, że lepiej, gdy początek tekstu jest konkretny: coś opisuje, o czymś informuje, czymś intryguje. Nawet jeśli dotyczy ogólniejszego problemu" ${ }^{16}$. Inna autorka przypomina przy okazji wywiadu: „Zacznij ciekawie. Czasem może być zaczepnie, dowcipnie, ale nie na siłę. To musi mieć sens dla tekstu, ponieważ pierwsze pytanie go ustawia"17.

Inne cele ma wstęp do tekstu naukowego. Tu nie ma nastawienia na maksymalizację atrakcyjności ani stworzenie więzi z odbiorcą, nie ma też przyzwolenia na ogólniki, truizmy i szablony. Celem jest przekazanie odbiorcy rzeczowych, precyzyjnych informacji związanych $z$ tematem i jego ujęciem, które mają go wstępnie przekonać o zasadności analiz i skłonić do zapoznania się ze szczegółami. Typowe treści we wstępie do pracy naukowej to: uzasadnienie podjęcia tematu, przedstawienie celu pracy, jej struktury, zbadanego materiału (i sposobu jego wyboru), a także „mówienie o stanie dotychczasowych rozwiązań teoretyczno -metodologicznych, które są dokumentowane przeglądem znanej autorowi literatury na dany temat" ${ }^{\prime 1}$. Niezmiernie istotnym elementem wstępu (a w przypadku dłuższych tekstów - początkowego rozdziału) jest zdefiniowanie kluczowych pojęć. Jest to fundament dalszych rozważań, bez którego znacznie trudniej utrzymać konsekwencję i dyscyplinę myślową w całym wywodzie.

Wstęp tekstu popularnonaukowego Anna Starzec uznaje za jeszcze bardziej obciążony funkcjonalnie i wymienia trzy główne funkcje: informacyjną (tematyka tekstu), przywołującą (ustalenie wspólnej nadawcy i odbiorcy wiedzy o świecie) oraz stymulującą (zachęcanie do lektury i zapoznania się z zagadnieniem). Wykorzystuje się tu między innymi kontrast: przywołane wiadomości są tłem wykazania, że sytuacja jest inna niż potoczne przekonania, że odkryto nowe fakty itp. Zainteresowaniu i zaktywizowaniu (zaproszeniu do dialogu) odbiorcy służą między innymi pytania, wyliczenia, paralele, oceny ${ }^{19}$.

$$
* * *
$$

Jak wynika z przeglądu, początek tekstu pełni wiele ważnych zadań związanych $\mathrm{z}$ tematyką, intencjami nadawcy i zakładanym odbiorcą. $\mathrm{Z}$ tego względu

${ }^{15}$ R. Gluza, Pisz, nie nudź, [w:] Biblia dziennikarstwa, red. A. Skworz, A. Niziołek, Kraków 2010, s. 51.

16 Ibidem.

${ }^{17}$ K. Bielas, Nie dla narcyzów, [w:] Biblia dziennikarstwa, s. 485.

18 A. Starzec, op. cit., s. 202.

${ }^{19}$ Ibidem. 
jego konstruowaniu trzeba poświęcić szczególnie dużo czasu i wysiłku ${ }^{20}$, „,dobry tekst nie może się byle jak zaczynać" 21 . Bardzo istotne jest zadbanie o konkretność i oryginalność - jak przekonuje Piotr Wierzbicki, „dobrych sposobów zaczynania tekstu są tysiące"22.

\section{Co znajduje się we wstępie do rozprawki - analiza prac uczniowskich}

Materiał badawczy stanowiło około stu rozprawek napisanych przez uczniów klas pierwszych szkół ponadgimnazjalnych różnego typu ${ }^{23}$. Prace dotyczyły czterech tematów:

1. Czy zgadzasz się ze stwierdzeniem, że człowiek to istota społeczna? (SP) ${ }^{24}$

2. Rozum czy uczucia — czym bardziej powinniśmy kierować się w życiu? (RU)

3. Przypadek, przeznaczenie, Bóg czy człowiek - co przede wszystkim kieruje ludzkim życiem? (PRZ)

4. Dlaczego, Twoim zdaniem, współcześni twórcy w swoich dziełach chętnie odwołują się do tradycyjnych baśni, mitów, legend? (BM)

Analizowane tematy różniły się stopniem trudności, wynikającym z tego, że dopuszczały różną liczbę stanowisk, czyli dawały uczniowi mniejszy lub większy wybór (SP oraz RU — dwa stanowiska, PRZ - cztery, BM - wiele). Chodziło o sprawdzenie, czy stopień trudności tematu (wyróżniany ze względu na liczbę możliwych stanowisk ${ }^{25}$ ) wpływa na sposób konstrukcji i treść wstępu.

Zdecydowana większość prac miała wstęp. Był on wydzielony graficznie i miał objętość jednego akapitu, złożonego zwykle z dwóch do pięciu zdań. Wynika stąd, że uczniowie mają świadomość, że rozprawka nie powinna zaczynać się argumentacją. Na tym jednak zazwyczaj wiedza o dobrym wstępie się kończy — bardzo rzadko zdarzało się poprzedzenie argumentów i przykładów czymś naprawdę konkretnym i przydatnym. Przyjrzyjmy się najbardziej charakterystycznym ,zachowaniom tekstowym” uczniów — typowym elementom treści wstępów.

20 J. Maćkiewicz, op. cit., s. 41.

${ }^{21}$ P. Wierzbicki, op. cit., s. 106.

22 Ibidem.

${ }^{23}$ Wypracowania powstały w ramach projektu badawczego „Umiejętności językowe i tekstotwórcze uczniów klas pierwszych szkół ponadgimnazjalnych powiatu kwidzyńskiego", realizowanego od $2011 \mathrm{r}$ z z inicjatywy władz samorządowych powiatu.

${ }^{24} \mathrm{~W}$ nawiasie podaję skrót, który będzie towarzyszył przykładom z prac na dany temat.

${ }^{25}$ Im bardziej otwarte pytanie, tym rozprawka trudniejsza - por. M. Nagajowa, Ćwiczenia w mówieniu i pisaniu, Warszawa 1977, s. 230-231. 
Jeden z często stosowanych typów wstępu to teza obudowana formułami metatekstowymi:

[1] Celem moich rozważań jest odpowiedź na pytanie: co przede wszystkim kieruje ludzkim życiem? W mojej pracy będę starała się udowodnić tezę, iż ludzkim życiem kieruje przypadek oraz sam człowiek. (PRZ)

[2] Często spotykamy się ze stwierdzeniem, że człowiek to istota społeczna. Czy tak jest naprawdę? W tej pracy podam przykłady potwierdzające wyżej wymienione stwierdzenie. (SP)

[3] Celem mojej rozprawki jest wykazanie, że w życiu powinniśmy kierować się uczuciami, a nie rozumem. Poprę swoją tezę odpowiednimi argumentami. (RU)

Typowe dla takiego 2-3-zdaniowego wstępu jest charakterystyczne słownictwo związane z realizowanym gatunkiem i przekonywaniem: rozprawka, praca, cel, pytanie, stwierdzenie, udowodnić, poprzeć, potwierdzić tezę, argumenty, przy$k ł a d y$. Tezę przytaczano w całości lub fragmentarycznie, zwykle czyniąc z niej składową wypowiedzenia złożonego.

Inny popularny typ wstępu to teza, której towarzyszą dwa, trzy zdania zawierające ogólniki mniej lub bardziej związane z tematem:

[4] Twórczość współczesna jest bardzo różnorodna i nieprzewidywalna. Wśród dzieł nowoczesnych możemy znaleźć wiele nawiązań do tradycji bądź do kultowych, wszystkim znanych baśni, legend lub mitów. Ukazanie odbiorcy czegoś nowego przez na przykład postać, którą zna z dzieciństwa, w pewnym stopniu gwarantuje większe zrozumienie. (BM)

[5] Wartości, które wpływają na postępowanie człowieka, mogą być wielorakie. Dla jednych będzie to przeznaczenie, dla innych przypadek, zaś jeszcze dla innych drugi człowiek. Te wartości kierują postępowaniem człowieka w różnych sferach życia. Mogą pozytywnie lub negatywnie wpływać na nasze postępowanie. Uważam, że najważniejszym „bodźcem”, który kieruje nas w życiu, pomijając te wcześniej wspomniane, jest Bóg. Postaram się przytoczyć kilka argumentów, aby potwierdzić wyżej postawioną przeze mnie tezę. (PRZ)

Typowe dla tej poetyki są zdania, które przekazują treści powszechnie uznawane za oczywiste. Choć ogólnikowość jest cechą trudno mierzalną, w znacznej mierze też subiektywną, przynajmniej część treści da się ocenić jako przydatne lub zbędne - na przykład usuwając wybrane zdania i sprawdzając, czy wywód stał się przez to niekompletny. Pierwsze zdanie w przykładzie [4], będące bez wątpienia truizmem, można by wykreślić bez większej szkody dla treści i dalszego ciągu tekstu - trudno dostrzec, co miałoby wnieść do tematu. Z kolei w przykładzie [5] autor(ka) w czterech pierwszych zdaniach referuje tezę, osiągając sporą objętość dzięki konsekwentnie stosowanemu (czy świadomie?) zabiegowi, polegającemu na tym, że kolejne zdanie jest uszczegółowieniem treści poprzedniego (drugie - pierwszego, czwarte - trzeciego). Oba przytoczone wstępy można by znacznie skrócić, redukując treści powtarzające się lub mało potrzebne w związku z postawionym pytaniem.

Kolejny typ uczniowskiego wstępu to taki, w którym są tylko ogólniki, truizmy, banały: 
[6] Na naszej Ziemi spotykamy wiele żywych istot. Jedną z nich jest człowiek. Od początku naszego życia jesteśmy otaczani przez innych ludzi, żyjemy w społeczeństwie. Zostaliśmy stworzeni, by żyć w nim. (SP)

[7] W dzisiejszych czasach ludzie mają mało czasu i żyją w ciągłym biegu. Kierują się swoimi ideałami, dążąc do określonego celu. W tym szybkim tempie życia podejmują często instynktowne decyzje. Jedni ufają rozumowi, inni uczuciu. Nie wszystkie nasze postanowienia są jednak trafne. Czym więc powinniśmy się kierować? Rozumem czy uczuciami? (RU)

[8] Niejednokrotnie zastanawiałam się nad tym, co kieruje ludzkim życiem. Przypadek, przeznaczenie, Bóg czy człowiek? Na to pytanie każdy odpowie nieco inaczej, gdyż jest to sprawa indywidualna. Jednak ja postaram się odpowiedzieć na to pytanie w poniższych argumentach. (PRZ)

Nie ma tu tezy — zamiast niej może pojawić się przytoczenie pytania zawartego w temacie pracy. W przykładzie [6] dwa pierwsze zdania są zbędne, na podstawie dwóch kolejnych można jedynie domyślać się, że autor(ka) raczej zgadza się z twierdzeniem, że człowiek jest istotą społeczną. Podobnie w kolejnym przytoczonym wstępie [7] — znowu na początek trzy zdania niepotrzebne (bez widocznego związku z tematem), po nich, zamiast jasnego stanowiska, powtórzenie pytania zawartego w temacie. W przykładzie [8] znajdziemy tylko powtórzenie pytania z tematu i obietnicę odpowiedzi w dalszej części pracy.

Kolejny typ wstępu składa się z tezy oraz pierwszego argumentu, ewentualnie mniej lub bardziej świadomej „zapowiedzi” argumentów w rozwinięciu:

[9] Zgadzam się, że człowiek jest istotą społeczną, ponieważ lubi pomagać innym osobom w ciężkich chwilach. Uzasadniając moje zdanie, podam kilka przykładów potwierdzających, że człowiek jest istotą społeczną. (SP)

[10] W naszym życiu przydarza się wiele sytuacji, jedne można nazwać przeznaczeniem, inne przypadkiem. Według mnie przede wszystkim ludzkim życiem kieruje przypadek, ponieważ nigdy nie wiadomo, jak się potoczy dany dzień, tydzień. Postaram się to udowodnić w kilku argumentach. (PRZ)

Dla tego typu treści charakterystyczne są spójniki przyczynowe bo oraz ponieważ. Wprowadzają one elementy uzasadnienia, które mogą - ale wcale nie muszą — być uszczegółowione w rozwinięciu pracy. Niemniej jednak jest to krok w dobrym kierunku - zgodnie z retoryczną zasadą 3P we wstępie zasadne jest skrótowe zapowiedzenie (niemal) całej argumentacji (,powiedz, co powiesz”). W ten sposób przygotowuje się odbiorcę na to, co nastąpi (choć nie zdradza wszystkiego) i ułatwia mu orientację w strukturze pracy ${ }^{26}$. Ważna jest tu jednak precyzja wypowiedzi, której zabrakło we wstępie [10] — uczeń tak skonstruował ostatnie zdanie, że można je zrozumieć na dwa sposoby (udowodni, że życiem kieruje przypadek, albo udowodni, że nigdy nie wiadomo, jak potoczy się dzień).

Treści innego rodzaju były w badanych wstępach rzadkością. Nieliczne przykłady:

[11] Rozum to wartość, którą powinniśmy się kierować w naszym życiu. Pomaga przemyśleć i przeanalizować nasze postępowanie, ale także uczucia i ich pochodzenie. Właśnie dlatego rozum

${ }^{26}$ M. Rusinek, A. Załazińska, op. cit., s. 112. 
góruje nad uczuciami, a losy bohaterów dramatów Williama Szekspira „Makbet” i „Romeo i Julia” oraz powieści fantastycznej Joanne Kate Rowling pt. „Harry Potter” pokażą tę zależność. (RU)

[12] Dzisiejsze społeczeństwo dzieli się na dwie grupy ludzi. Do pierwszej grupy należą osoby statyczne, które trzy razy się zastanowią zanim podejmą decyzje. Mają udane życie, nie wiedzą, co to spontaniczność. Natomiast drugą grupę tworzą ludzie, którzy żyją chwilą, nie wychylają się do przodu. Ich życie polega na spontaniczności. [...] (RU)

[13] Powiedziane jest, że najdłuższą drogą, jaka istnieje, jest ta z serca do rozumu. Codziennie, we wnętrzu każdego z nas toczy się walka. Wielu nie wie, czy lepiej będzie sugerować się uczuciami, czy jednak rozsądkiem, natomiast moim zdaniem, aby dobrze kierować swoim życiem i być szczęśliwym, musimy słuchać głosu serca. (RU)

W przykładzie [11] autor(ka) zapowiada, do jakich utworów się odwoła, by przekonać o słuszności swojego stanowiska. Nasyca w ten sposób wstęp konkretami (nazwy własne są precyzyjną informacją) i ściśle wiąże go z rozwinięciem. Ukazanie na początku, jakie dzieła zostaną przytoczone w rozwinięciu pracy, dowodzi, że autor(ka) ma pomysł na całą wypowiedź. Niestety w większości wstępy można swobodnie wymieniać między pracami z taką samą tezą, co wskazuje na ich ogólnikowość i szablonowość oraz przeczy temu, że tekst jest zamkniętą strukturą. Dobry wstęp to wstęp pasujący do tej jednej pracy, a nie do każdej pracy na dany temat.

W przykładzie [12] nadawca krótko charakteryzuje dwie grupy ludzi, osiągając w ten sposób dwa cele. Pierwszy to przywołanie pewnych informacji o rozumie i uczuciach, czyli dwóch pojęciach kluczowych dla tematu, między którymi należy wybierać. Drugi cel to ukazanie, że jedno i drugie rozwiązanie ma swoich zwolenników - przedstawienie różnych możliwych stanowisk dowodzi wiedzy na dany temat, uwypukla sensowność pytania, podkreśla, że wybór nie jest oczywisty (a zatem ma sens zastanawianie się nad tym).

Ostatni z zacytowanych w tym miejscu wstępów - [13] — rozpoczyna się przytoczeniem złotej myśli, co daje wiele korzyści: dotyczy podstawowych pojęć tematu, intryguje, ukazuje zasadność problemu.

Przegląd typowych i mniej typowych treści we wstępach badanych rozprawek zamykam informacją statystyczną — tabela 1 ukazuje, w jakiej części rozprawek pojawiały się rozmaite elementy.

Tabela 1. Częstość występowania różnych elementów wstępu do rozprawki

\begin{tabular}{|l|c|}
\hline \multicolumn{1}{|c|}{ Element wstępu } & Częstość występowania [\%] \\
\hline teza & 72 \\
\hline $\begin{array}{l}\text { truizmy, ogólniki, powtarzanie } \\
\text { treści tematu }\end{array}$ & 41 \\
\hline $\begin{array}{l}\text { szablonowe formuły metatek- } \\
\text { stowe }\end{array}$ & 37 \\
\hline
\end{tabular}




\begin{tabular}{|l|c|}
\hline $\begin{array}{l}\text { argument lub ,zapowiedź” } \\
\text { argumentacji }\end{array}$ & 17 \\
\hline $\begin{array}{l}\text { próba objaśnienia kluczowych } \\
\text { pojęć }\end{array}$ & 13 \\
\hline $\begin{array}{l}\text { zapowiedź treści w rozwinięciu } \\
\text { (innych niż argumentacja) }\end{array}$ & 7 \\
\hline
\end{tabular}

Źródło: opracowanie własne.

Podsumujmy i uzupełnijmy dotychczasowe ustalenia wynikające z ilościowej i jakościowej analizy wstępów.

Uczniowie na ogół tworzą wstęp do rozprawki, jednak najczęściej jest on krótki i ogólnikowy, nie wnosi do pracy niczego poza sformułowaniem stanowiska. Istnieje zależność między jakością wstępu a typem tematu: im bardziej otwarty, tym większe kłopoty ze stworzeniem wartościowego początku pracy.

Najczęściej obecnym typem treści we wstępie jest teza, ale nawet i to nie jest dla wszystkich piszących oczywiste. W ponad jednej czwartej prac uczniowie nie określili jasno swojego stanowiska względem problemu zawartego w temacie, co na przykład w świetle obowiązujących kryteriów oceny wypowiedzi argumentacyjnej na egzaminie maturalnym dyskwalifikuje pracę ${ }^{27}$.

Najczęstszą metodą zapełniania wstępu (żeby tylko był) było umieszczanie tam oczywistości i ogólników, luźno powiązanych w tematem. Truizmy i prawdy absolutne umieszczano często w dwóch pierwszych zdaniach pracy, które w efekcie zwykle można by bez najmniejszej szkody wykreślić. Takie „uniwersalne” wstępy zazwyczaj bardzo luźno wiążą się z resztą rozprawki — można je całkiem swobodnie wymieniać między pracami na taki sam temat i z taką samą tezą.

Drugi, niemal równie często stosowany zabieg (nierzadko łącznie z truizmami) to sięganie po rozbudowane formuły metatekstowe. Ich nadmiar zniechęca odbiorcę, od każdego nadawcy poza absolutnie początkującym oczekuje się, że tak skonstruuje wypowiedź, iż bez „łopatologicznego” zapowiadania odbiorca będzie czuł, co się właśnie dzieje.

Rzadko - mniej niż co piąta praca — zapowiadano argumenty, jakie pojawią się w rozwinięciu. Albo uczniowie nie wiedzą, że byłoby to bardzo pożądane, albo po prostu piszą wstęp, zanim zastanowią się, co będzie dalej.

Niezmiernie rzadko uczniowie próbowali — w sposób mniej lub bardziej świadomy - scharakteryzować kluczowe pojęcia lub obiekty tematu. W temacie SP określenie, czym charakteryzuje się istota społeczna, to pierwszy krok do udowodnienia, że człowiek jest lub nie jest taką istotą; w rozprawce RU krótki opis natury uczuć i rozumu to znakomity fundament opowiedzenia się za jednym $\mathrm{z}$ nich. Z kolei w wielu pracach na temat PRZ widać było, że uczniowie bardzo powierzchownie, intuicyjnie posługują się pojęciami ,przypadek” czy „przezna-

${ }^{27}$ Centralna Komisja Egzaminacyjna, Informator o egzaminie maturalnym z języka polskiego od roku szkolnego 2014/2015, Warszawa 2013, s. 140. 
czenie", przez co argumentacja bywała całkiem chybiona (przykład mający pokazywać, że życiem rządzi przeznaczenie, pokazywał raczej, że przypadek).

Rozważania dotyczące pojęć kluczowych tematu pojawiały się czasem w głównej części pracy albo i w zakończeniu - co można widzieć jako kolejny znak tego, iż wstęp pełni raczej funkcję niezobowiązującej rozgrzewki niż integralnej, ważnej części wypowiedzi argumentacyjnej.

Wszystkie wymienione tu cechy sprawiają, że badane wstępy nie tylko nie zaciekawiają, lecz także w wielu przypadkach zniechęcają do lektury. Co ważne, mierne wstępy zawierały zarówno prace ogólnie niedobre, jak i całkiem ciekawe. Zwłaszcza ten ostatni przypadek skłania do refleksji - czy napisanie dobrego wstępu jest po prostu bardzo trudne i nawet najlepsi uczniowie często sobie z tym nie radzą, czy też piszący tę część tekstu lekceważą, traktują jak składnik pozbawiony większego znaczenia. A może są uczeni, że wstęp do rozprawki to twór sztampowy?

Pytania te wprowadzają w tematykę drugiej części artykułu. Ponieważ diagnoza kompetencji uczniowskich wypada bardzo pesymistycznie, potrzebny jest kolejny krok: wskazanie możliwych przyczyn ukazanego stanu, co z kolei może być punktem wyjścia działań zmierzających do poprawy sytuacji.

\section{Czynniki mogące wpływać na (nie)umiejętność tworzenia wstępu}

Można wymienić wiele czynników mogących przyczyniać się do opisanego stanu rzeczy, choć oczywiście trudno przesądzić, w jakim stopniu każdy z nich wpływa na poziom uczniowskich kompetencji. Ze względu na ograniczenie miejsca chciałbym krótko zwrócić uwagę na cztery zagadnienia:

1. możliwe trudności ze znalezieniem dokładniejszych informacji lub ćwiczeń pomagających napisać dobry wstęp do rozprawki;

2. problemy z tożsamością rozprawki jako gatunku;

3. niedostateczną pracę nad warsztatem pisarskim w szkole ponadgimnazjalnej;

4. powszechne (choć oczywiście niejawne) przyzwolenie na niską jakość wstępu do wypowiedzi.

Pierwszy czynnik jest ściśle związany z pomocami dydaktycznymi dla uczniów i nauczycieli. Okazuje się, że wcale niełatwo znaleźć publikację edukacyjną, która pomogłaby rozwijać umiejętność formułowania wstępu do rozprawki. Do takich wniosków prowadzi na przykład dokonany przeze mnie przegląd próbki podręczników gimnazjalnych - sprawdziłem, co o wstępie do rozprawki można znaleźć w piętnastu książkach należących do ośmiu serii podręcznikowych różnych wydawców. W niemal połowie pozycji (7) nie było żadnych wiadomości 
ani ćwiczeń dotyczących wstępu - ograniczono się do przypominania o sformułowaniu tezy lub hipotezy i różnego typu ogólników:

Wstęp służy wyjaśnieniu tematu, podaniu jego interpretacji ${ }^{28}$.

17. Rozprawkę rozpocznij od dwóch lub trzech zdań wprowadzających w problem.

18. Część wstępna - nawiązujemy do tematu, stawiamy tezę lub hipotezę.

Rozprawka powinna się składać z trzech zasadniczych części:

— wstępu, w którym formułujemy tezę lub hipotezę; tu też można uzasadnić przyczynę podjęcia danego tematu. [...]

W podręcznikach można znaleźć banki sformułowań przydatnych podczas tworzenia rozprawki, także do jej wstępu:

\section{POMOCNE SFORMUŁOWANIA}

Jak zacząc rozprawkę:

To zagadnienie interesowało mnie od dawna, więc postanowiłam / postanowiłem przyjrzeć mu się bliżej...

W swojej pracy postaram się zaprezentować... oraz przedstawić własne sądy na temat...

Wydawało mi się dotąd, że... jest oczywiste, jednak... skłoniło mnie do rozważenia tego raz jeszcze i zweryfikowania sądów

Sądzę, że warto się zastanowić nad kwestią... ponieważ...

Przedstawione szablony mają pomóc początkującym zapanować nad wywodem i realizować jego cel. Niektóre z nich istotnie pomogą — na przykład $W$ swojej pracy... przypomina, że podstawą wypowiedzi jest stanowisko ucznia w określonej sprawie; Sądzę, że warto... zachęca do wskazania istotności tematu, braku oczywistej odpowiedzi na jakieś pytanie czy powszechnej zgody w jakiejś sprawie. Inne budzą wątpliwości, na przykład szablon To zagadnienie... zachęca ucznia do hipokryzji i utwierdza go w przekonaniu, że wszystko tu jest sztuczne i udawane — podsuwanie takich sformułowań nie zmieni tego, że rozprawkę pisze się wyłącznie dlatego, że zadał ją nauczyciel, i że wiele rozprawkowych tematów dotyczących klasyki literatury i kultury wysokiej nie budzi najmniejszego zainteresowania przynajmniej części uczniów. Zagrożeniem ze strony wszelkich szablonów jest ich utrwalenie się i mechaniczne stosowanie w każdej wypowiedzi. Pokusa bezwysiłkowego sięgnięcia po bezpieczną formułę wygrywa z dążeniem do tego, by przekonywanie było naturalne, indywidualne. Sztuczna oprawa odbiera moc wszelkim argumentom.

Dokładniejsze, pomocne treści dotyczące wstępu były w zbadanych podręcznikach bardzo rzadkie. To, co przytaczam dalej, to nie wybrane przykłady reprezentujące większy materiał, lecz wszystko, co dało się znaleźć:

ĆWICZENIE: Napisz wstęp do rozprawki, w którym zdefiniujesz pojęcia zawarte w temacie.

Analiza tematu „Tolerancja — wartość czy słabość we współczesnym świecie?”

${ }^{28}$ Nie podaję źródeł cytatów z podręczników, gdyż celem tego artykułu nie jest ocena konkretnych publikacji, lecz zarysowanie ogólnej sytuacji. 
Dokładnie rozważ temat rozprawki, odpowiadając na pytania:

Czym jest tolerancja? Jak rozumiesz to słowo? Z czym Ci się kojarzy?

Jak słowo tolerancja definiowane jest w słowniku języka polskiego?

Czym różni się tolerancja od obojętności? Na czym polega wieloznaczność tego pojęcia?

W relacjach z jakich wydarzeń najczęściej mówi się o tolerancji lub jej braku? Kiedy możesz zetknąć się z tym problemem w życiu codziennym?

Oba cytaty łączy jedna podstawowa sprawa: zachęcają do pochylenia się nad słowami i pojęciami kluczowymi tematu i pracy. Jest to bardzo istotne, zwłaszcza gdy temat zawiera słowa trudne bądź takie, które można rozumieć na wiele sposobów. Nie chodzi tu rzecz jasna o to, by uczeń zdefiniował te pojęcia, bo z pewnością często przekracza to jego możliwości, ale choćby o próbę dookreślenia fundamentalnych terminów problemu, ukazanie intuicyjnego rozumienia oraz świadomości, że takie działanie należy podjąć przed zajęciem stanowiska i jego uzasadnianiem. Taka operacja ułatwi uczniowi postawienie tezy i dobieranie argumentów, jest też najlepszym dowodem właściwego zrozumienia tematu. Pomoże też odbiorcy tekstu w zrozumieniu intencji nadawcy, a nauczycielowi w ocenie poprawności toku myślenia. Przykład dotyczący tolerancji pokazuje kilka dróg do możliwie najdokładniejszego zakreślenia znaczenia pojęcia: przypomina, że można i warto korzystać z pomocy, na przykład słowników, a także zachęca do wskazania różnic między pojęciami bliskimi albo z sobą łączonymi (tolerancja — obojętność).

Zamykające analizę tematu pytania wskazują na istotność problemu (nie jest wyimaginowany), aktywizują też życiowe doświadczenia ucznia (nie tylko literatura). Jeśli uczeń przedstawi, czym dla niego jest tolerancja, znacznie łatwiej mu świadomie odpowiedzieć na pytanie, czy jest ona wartością, czy słabością.

$* * *$

Inne pomoce edukacyjne reprezentuje w niniejszych analizach poradnik dla maturzystów przygotowany przez Instytut Badań Edukacyjnych. Czytamy tam o wstępie (cytuję wszystkie znalezione informacje):

Wstęp powinien spełniać kilka funkcji:

— wprowadzać czytelnika w problematykę, której dotyczyć będzie rozwinięcie;

— zachęcać do lektury całości wypracowania;

- przedstawiać stanowisko autora wobec problemu podanego w temacie.

Dobry wstęp do rozprawki powinien spełniać trzy warunki:

— powinien być rzeczowy (dotyczyć problemu podanego w temacie),

— powinien być efektowny (zachęcać do lektury całości), macie $)^{29}$.

- powinien zawierać tezę (przedstawiać stanowisko autora wobec problemu podanego w te-

29 Instytut Badań Edukacyjnych, Jak przygotować i napisać rozprawkę maturalną? Poradnik, Warszawa 2014, s. 4, 19. 
Niewątpliwie słuszne ogólne uwagi nie przybliżają do praktycznych rozwiązań. Uczeń dowie się, że ma rzeczowo wprowadzić w problematykę, ale nie zobaczy, na czym ta rzeczowość może polegać; przeczyta, że ma być efektownie, ale sam będzie musiał wymyślić, jak tę efektowność (próbować) uzyskać. Analizowane prace przekonują, że w większości przypadków się to nie uda i ,wprowadzenie w problematykę" sprowadzi się najpewniej do kompilacji banałów, oczywistości i stereotypów.

Przegląd ów ukazuje, że uczniom i nauczycielom może brakować pomocy ze strony (autorów) publikacji edukacyjnych. Oczywiste jest, że podręcznik z racji ograniczeń objętościowych nie może zawierać rozbudowanych wiadomości o wszystkim, ale łatwo odnieść wrażenie, że dałoby się miejsce poświęcone rozprawce zagospodarować z większym pożytkiem dla odbiorców.

Druga istotna przyczyna trudności z zaprojektowaniem ciekawego, oryginalnego i przydatnego merytorycznie wstępu to hybrydyczna tożsamość gatunkowa rozprawki. Łączy ona cechy tekstów naukowych lub popularnonaukowych (rozprawka to 'mała rozprawa', czyli uproszczona odmiana podstawowego gatunku naukowego ${ }^{30}$ ) z cechami gatunków retorycznych (argumenty, przykłady, figury retoryczne). To niewątpliwie utrudnia uczniowi właściwy dobór treści: inne zadania ma wstęp tekstu (popularno)naukowego, inne - wypowiedzi retorycznej, $\mathrm{i}$ innymi sposobami te cele się realizuje. Elementy naukowe to przede wszystkim próba dookreślenia podstawowych terminów wywodu czy uzasadnienie podjęcia tematu (przyczyny merytoryczne). Elementy retoryczne to na przykład zainteresowanie odbiorcy i przygotowanie gruntu pod przekonanie go do swojego stanowiska. Harmonijne pogodzenie składników z różnych sfer komunikacji nie jest na pewno zadaniem łatwym, co nie znaczy, że niewykonalnym.

$\mathrm{Na}$ niemałe trudności merytoryczne nakładają się problemy, które można określić jako psychologiczne albo społeczne - rozprawka to forma wypowiedzi, której nie lubi zarówno wielu uczniów, jak i nauczycieli. Jawi się ona bowiem jako gatunek nieprzydatny życiowo — typowo szkolny, sztuczny i schematyczny. W sytuacji szkolnej mało sensowne jest przekonywanie odbiorcy, że nadawca ma prawo się wypowiadać na dany temat, ponieważ nadawca uczeń wykonuje polecenie odbiorcy nauczyciela; nadawca nie musi się przedstawiać, gdyż odbiorca go zna; nie widać potrzeby zachęcania odbiorcy do przeczytania pracy, gdyż wiadomo, że nauczyciel ma obowiązek sprawdzić rozprawkę, którą zadał — bez względu na to, czy wstęp (i dalszy ciąg) będzie atrakcyjny, czy nie.

Jedyną motywacją towarzyszącą pisaniu wstępu i całej pracy pozostaje często chęć uniknięcia oceny niedostatecznej, gdyż uczniowie nie zdają sobie sprawy

${ }^{30}$ M. Nagajowa, Sztuka dobrego pisania i mówienia, Warszawa 2003, s. 110. 
(bo nikt im o tym nie powiedział), że pisanie rozprawek pomaga im rozwijać wiele umiejętności wykorzystywanych na co dzień (między innymi jasne, precyzyjne wyrażanie swojego stanowiska $\mathrm{w}$ danej sprawie i uzasadnianie go przez przytaczanie przekonujących argumentów i obrazowych przykładów ${ }^{31}$ ).

$$
* * *
$$

Trzeci możliwy powód niezadowalającej sytuacji jest taki, że w szkole ponadgimnazjalnej mało pracuje się nad warsztatem pisarskim i (zbyt) mało pisze. Praca nad wypowiedzią argumentacyjną zaczyna się w gimnazjum, ale nie może tam się kończyć. Zalecenia i banki sformułowań na początku mogą się przydać, potem coraz bardziej przeszkadzają. Podczas pierwszych prób metatekstowe formuły spójnościowe pomogą zapanować nad wywodem ${ }^{32}$, ale potem powinny ustępować miejsca wyznacznikom semantycznym. Analizowane prace, pisane pod koniec klasy pierwszej liceum lub technikum (różne klasy, różne szkoły, różni nauczyciele), pokazują, że u większości uczniów umiejętności tekstotwórcze nie zmieniły się od czasów gimnazjalnych. Martwi niedostatek logicznego myślenia czy samooceny toku rozumowania. Brak ćwiczeń warsztatowych i omawiania prac pod kątem struktury wywodu może sprawić, że tak pozostanie do egzaminu maturalnego.

Nikły rozwój warsztatu może też się brać z pisania prac na źle sformułowane tematy — nudne, nieprzemyślane (zadane na zasadzie „zobaczymy, co napiszą”) itp. Dobry temat rozprawki na poziomie ponadgimnazjalnym powinien zawierać pytanie, na które nie ma jednej, oczywistej odpowiedzi, aby skłonić ucznia do samodzielnego myślenia, poszukiwań, podejmowania decyzji, dokonywania wyborów ${ }^{33}$. Lepiej nie umieszczać w temacie słów naprawdę trudnych do zdefiniowania (choć często używanych na co dzień intuicyjnie), ponieważ niezrozumienie kluczowego terminu to niejednokrotnie przyczyna nietrafności całej argumentacji lub pojawienia się pustosłowia, którym uczeń próbuje zrekompensować swą bezradność. Przy formułowaniu tematów warto też, przynajmniej od czasu do czasu, uwzględnić uczniowskie pasje i zainteresowania. Zarówno wstęp, jak i cała rozprawka wymaga bowiem nie tylko świadomości językowej i tekstowej, lecz także (a może przede wszystkim) pewnej wiedzy na dany temat.

$$
* * *
$$

Ostatnia możliwa przyczyna niedbałości o wstęp do rozprawki ma charakter ogólniejszy, nie dotyczy tylko tej formy wypowiedzi. Mianowicie w różnych

${ }^{31}$ E. Bańkowska, Rozprawka - przygoda człowieka myślacego, [w:] Na językoznawczych ścieżkach. Prace ofiarowane Profesorowi Jerzemu Podrackiemu, red. A. Mikołajczuk, R. Pawelec, Warszawa 2007, s. 40.

${ }^{32}$ M. Nagajowa, Sztuka ..., s. 115-116.

${ }^{33}$ E. Bańkowska, op. cit., s. 35. 
sytuacjach komunikacyjnych można odnieść wrażenie, że mimo podkreślanej w literaturze wagi wstępu w praktyce traktuje się go lekceważąco, milcząco przyzwala na jego bylejakość. Wielu nadawców nie wysila się przy tworzeniu początku wypowiedzi i nie oczekuje tego od innych; przyjmują, że wstęp to takie zło konieczne, a to, co istotne, pojawi się dopiero w części głównej tekstu.

Takiej postawy nikt nigdzie oczywiście nie wyraża wprost, zwłaszcza na piśmie; można tropić tylko jej podskórne, subtelne przejawy. Na istnienie zjawiska mogą wskazywać słowa Piotra Wierzbickiego w Ćwiczeniach stylistycznych: „Niektórzy [...] uważają, że zanim się przystąpi do rzeczy, trzeba napisać kilka zdań wstępu [...]. Wstęp i zakończenie mają się — według nich — luźno wiązać z tematem i mają mieć charakter ogólnikowy"34. Kim są ci oni, autor nie wyjaśnia, ale może tu chodzić o różne osoby: nauczyciela, autora podręcznika, ucznia. A także egzaminatora i urzędnika edukacyjnego, ponieważ drugi objaw bardzo liberalnego (a może już lekceważącego) podejścia do rozpoczęcia wypowiedzi argumentacyjnej można znaleźć w kryteriach oceny wypowiedzi argumentacyjnej na poziomie podstawowym egzaminu maturalnego z języka polskiego. Otóż jedyny wymóg co do zawartości wstępu polega na tym, że piszący ,powinien zrozumieć problem postawiony w poleceniu i sformułować stanowisko będące rozwiązaniem problemu"35. Sformułowanie tezy pasującej do tematu zapewnia więc komplet punktów za wstęp, a pozostałe treści tam zamieszczone nie mają znaczenia ${ }^{36}$. W tej sytuacji trudno się spodziewać, by pragmatycznie myślący uczeń włożył wiele wysiłku w coś, co nie przyniesie mu wymiernych korzyści.

\section{Podsumowanie}

Badane wstępy do rozprawek w ogromnej większości nie odpowiadały oczekiwaniom - były słabe merytorycznie i pragmatycznie. Wartość wielu z nich sprowadzała się do sformułowania tezy, choć co czwarta praca nie spełniła nawet tego elementarnego warunku. We wstępach królowały ogólniki, truizmy oraz „bezpieczne” szablony metatekstowe, poznane na początku pracy nad rozprawką. Na próżno apeluje Piotr Wierzbicki: „Powtórzmy jeszcze raz: tych wzorów nie należy bezmyślnie naśladować. Sposób rozpoczęcia [...] musi pasować do te-

${ }^{34}$ P. Wierzbicki, op. cit., s. 105.

35 Centralna Komisja Egzaminacyjna, op. cit., s. 140.

${ }^{36}$ Nieco lepiej wygląda sytuacja na poziomie rozszerzonym — we wstępie „Zdający powinien zrozumieć, jaki problem podejmuje autor w przedstawionym fragmencie tekstu oraz sformułować ten problem. Określenie problemu jest oceniane ze względu na to, czy jest zgodne $\mathbf{z}$ tekstem i czy jest pełne. Określenie problemu uważa się za pelne, jeśli praca zawiera zarówno odtworzenie problemu (na przykład w postaci pytania), jak i jego interpretację, czyli umieszczenie tego problemu w odpowiednim kontekście. Interpretacja problemu powinna być uzasadniona (na przykład wagę problemu można uzasadnić jego historycznymi uwarunkowaniami lub współczesnymi implikacjami)", por. ibidem, s. 149. 
matu. Tematów są tysiące. A ludzi są miliony. Ludzie nie powinni mówić i pisać jednakowo" 37 .

Bardzo trudno znaleźć pracę ze wstępem zawierającym istotne i przydatne treści, na przykład dookreślenie rozumienia kluczowych pojęć zawartych w temacie albo solidną zapowiedź argumentów w głównej części pracy.

Przyczyn tego stanu może być wiele, zarówno w samych uczniach, jak i w ich otoczeniu edukacyjnym. Uczniowie albo nie wiedzą, co warto umieścić we wstępie, albo wiedzą, ale nie potrafią tego zrobić w praktyce, albo też po prostu nie widzą potrzeby dbania o wstęp, skoro nikt tego nie wymaga ani nie docenia. W ich dydaktycznym otoczeniu warto zwrócić uwagę na niedostatek narzędzi (pomoce edukacyjne zawierają zwykle jedynie ogólniki), słabą pracę nad warsztatem retorycznym i tekstotwórczym w szkole ponadgimnazjalnej, a także (a może przede wszystkim) brak motywacji, zarówno wśród uczniów, jak i nauczycieli, który wynika między innymi stąd, że nie widzą praktycznych (życiowych, egzaminacyjnych) korzyści płynących z rozwijania umiejętności tworzenia zarówno dobrego wstępu, jak i całej rozprawki. W efekcie pisanie wypowiedzi argumentacyjnych zamiast być ćwiczeniem z samodzielnego myślenia ${ }^{38}$ jest wypełnianiem nudnego formularza.

Warto też podkreślić, że te niedobre nawyki są bardzo trwałe i nierzadko utrudniają (mniej lub bardziej) opanowanie innych umiejętności, potrzebnych w niektórych zawodach. Na przykład początkujący dziennikarze na ogół zaczynają swe teksty tak, jak zaczynali rozprawki — od banałów, ogólników i pustosłowia - mimo że bardzo szybko poznają podstawową zasadę mediów, że należy pisać przede wszystkim tak, by zachęcić odbiorcę do dalszej lektury, między innymi przechodząc od razu do konkretów. Wiele pracy kosztuje przełamywanie utrwalanej latami konwencji witania odbiorcy nudno i schematycznie.

Sądzę, że ten stan trzeba i można zmienić, przynajmniej w pewnym zakresie. Możliwe jest wyrobienie nawyku wstępnej (próby) analizy kluczowych terminów tematu. Da się także nauczyć skrótowego zapowiadania argumentów we wstępie — zapobiegnie to jego pisaniu przed ich zgromadzeniem, sprawi, że wstęp stanie się znacznie konkretniejszy i będzie pasował do tej i tylko tej pracy. Można też wypróbować z uczniami różne sposoby zaciekawiania odbiorcy — za pomocą anegdoty, błyskotliwego aforyzmu, paradoksu, cytatu itp. (zastanowić się wspólnie, gdzie ich szukać - nie tylko w internecie). Jednak najważniejsze w pracy nad wstępem wydaje się uświadomienie uczniom, jak wiele mogą zyskać lub stracić, zanim jeszcze na dobre zaczną. Jak przypomina Andrzej Sapkowski, nigdy się nie ma drugiej okazji, by zrobić pierwsze wrażenie.

\footnotetext{
37 P. Wierzbicki, op. cit., s. 108.

38 M. Nagajowa, ABC metodyki języka polskiego, Warszawa 1990, s. 184.
} 


\section{Bibliografia}

Bańkowska E., Rozprawka - przygoda człowieka myślacego, [w:] Na językoznawczych ścieżkach. Prace ofiarowane Profesorowi Jerzemu Podrackiemu, red. A. Mikołajczuk, R. Pawelec, Warszawa 2007, s. 35-41.

Bielas K., Nie dla narcyzów, [w:] Biblia dziennikarstwa, red. A. Skworz, A. Niziołek, Kraków 2010, s. 479-489.

Centralna Komisja Egzaminacyjna, Informator o egzaminie maturalnym z języka polskiego od roku szkolnego 2014/2015, Warszawa 2013.

Gluza R., Pisz, nie nudź, [w:] Biblia dziennikarstwa, red. A. Skworz, A. Niziołek, Kraków 2010, s. $48-61$.

Instytut Badań Edukacyjnych, Jak przygotować i napisać rozprawkę maturalną? Poradnik, Warszawa 2014.

Jagodzińska M., Psychologia pamięci. Badania, teorie, zastosowania, Gliwice 2008.

Maćkiewicz J., Jak dobrze pisać. Od myśli do tekstu, Warszawa 2010.

Nagajowa M., ABC metodyki języka polskiego, Warszawa 1990.

Nagajowa M., Ćwiczenia w mówieniu i pisaniu, Warszawa 1977.

Nagajowa M., Sztuka dobrego pisania i mówienia, Warszawa 2003.

Rusinek M., Załazińska A., Retoryka podręczna, czyli jak wnikliwie stuchać i przekonująco mówić, Kraków 2005.

Starzec A., Wspótczesna polszczyzna popularnonaukowa, Opole 1999.

Wierzbicki P., Ćwiczenia stylistyczne, Warszawa 1977. 